\title{
A dupla cicatriz: a ditadura brasileira e a vocalização feminina da memória traumática de Ana Maria Machado
}

\author{
The Double Scar: The Brazilian Dictatorship and the Feminine vocalization \\ of Traumatic Memory in the Work of Ana Maria Machado \\ La doble cicatriz: la dictadura brasileña y la vocalización femenina \\ de la memoria traumática de Ana Maria Machado \\ Roberto Vecchi*
Alessia Di Eugenio $^{* *}$
}

\section{Resumo}

Uma dupla cicatriz, a das experiências traumáticas da ditadura brasileira e a da difícil vocalização feminina dessa memória contra o esquecimento, atravessa os dois romances de Ana Maria Machado, Tropical sol da liberdade (1988) e Canteiros de Saturno (1991). Pioneiros entre as produções literárias escritas por mulheres e tendo como contexto os anos de chumbo e a época da redemocratização, essas obras permitem confirmar o papel antecipador da literatura na restituição e reconstrução desse passado brasileiro e, ao mesmo tempo, desmontar e desafiar a tradição androcêntrica da escrita da história. Em particular, os dois textos, soldando a esfera privada e o espaço público, e encenando ou construindo uma reflexão metaliterária, colocam as duas dimensões da questão de "gênero": a reflexão sobre a busca da forma da escrita (gênero) para contar e construir uma leitura alternativa da história e uma memória feminina nas suas especificidades de pontos de vista e vivências (gênero).

Palavras-chave: memória feminina, ditadura militar, literatura, Ana Maria Machado.

\section{Abstract}

A double scar, the traumatic experiences of the Brazilian dictatorship and the difficult female vocalization of this memory against oblivion, runs through Ana Maria Machado's two novels, Tropical Sol da Liberdade (1988) and Canteiros de Saturno (1991). As pioneering texts among literary productions written by women, and having as context the lead years and the period of redemocratization, they allow us to affirm the anticipatory role of literature in the restitution and reconstruction of this Brazilian past. At the same time, they also allow us to dismantle and challenge the androcentric tradition of history writing. In particular, the two texts, welding the private with the public and staging or constructing a metaliterary reflection, emphasize the two dimensions of the issue: the search for a form of writing (genre) to tell and build an alternative reading of history and a feminine memory in its specificities of viewpoints and experiences (gender).

Keywords: female memory, military dictatorship, literature, Ana Maria Machado.

\begin{abstract}
Resumen
Una doble cicatriz, las experiencias traumáticas de la dictadura brasileña y la difícil vocalización femenina de esta memoria contra el olvido, recorren las dos novelas de Ana Maria Machado, Tropical Sol da Liberdade (1988) y Canteiros de Saturno (1991). Los textos, pioneros entre producciones literarias escritas por mujeres, y que tienen como contexto los años de la represión y la época de la redemocratización, permiten afirmar el papel anticipatorio de la literatura en la restitución y reconstrucción de este pasado brasileño $\mathrm{y}$, al mismo tiempo, desmantelar y desafiar la tradición androcéntrica de escritura de la historia. En particular, los dos textos, que unen la espera privada y el espacio público y organizan o construyen una reflexión meta-literaria, plantean las dos dimensiones de la cuestión del "género": la reflexión sobre la búsqueda de la forma de escribir (género) para contar y construir una lectura alternativa de la historia y una memoria femenina en sus especificidades de puntos de vista y experiencias (género).
\end{abstract}

Palabras-clave: memoria femenina, dictadura militar, literatura, Ana Maria Machado.

\footnotetext{
* Università di Bologna, Bolonha, Itália. Dorcid.org/0000-0001-5982-0810. E-mail: roberto.vecchi@unibo.it

** Università di Bologna, Bolonha, Itália. (Dorcid.org/0000-0002-5648-2438. E-mail: alessia.dieugenio2@ unibo.it
} 
Cicatriz é uma palavra que remete de imediato, mesmo que só no plano de impressões, ao trabalho da memória. Não só em virtude de uma instigante hipótese etimológica - Márcio Seligmann-Silva (1999, p. 46) sugere que, em português, esquecer e cicatriz remetem ambas ao verbo latim cadere -, mas também porque a cicatriz é uma poderosa figura que absorve a memória do trauma e, pelo corpo, a projeta no espaço público. Nesse sentido, Aleida Assmann inscreve a cicatriz como um poderoso mediador da memória: de uma memória corpórea largamente "mais fiel do que a memória mental" (Assmann, 2002, p. 273, tradução nossa). Criase assim um paradoxo que, desde logo, desvenda a proximidade das cicatrizes e da literatura: como a experiência mais extrema e intransitiva da dor pode se tornar, pelo contrário, compartilhável e comunicativa. Isso ocorre através da exegese das cicatrizes que se podem tornar signos, assim como acontece no texto literário.

No caso do Brasil, das cicatrizes da sua história contemporânea, ainda abertas, como atestam as discussões dramáticas de hoje em volta das consequências da Comissão da Verdade, o aspecto - a aporia - de um passado ainda substancial e literalmente impróprio é algo bastante evidente. Há como um paradoxo que obtura o acesso ao passado - um acesso que, como os Memory and Trauma Studies demonstram, numa reflexão que confronta um paradigma da Shoah com os riscos do esquecimento contemporâneos, é sempre tradutório, diferencial, incoincidente. Dessa forma, por um lado, temos uma damnatio memoriae decretada inclusive com tecnologias jurídicas sofisticadas, em que se pode incluir também uma lei da anistia, que funciona em parte como matriz de amnésia; por outro lado, temos o recuo do autoritarismo no período da assim chamada abertura política, que coincidiu com uma eclosão de memórias pessoais, fragmentárias e traumáticas e conseguiu formar um imediato e tópico uso terapêutico da escrita subjetiva, mas que não estabeleceu um espaço compartilhado de memória pública. Substancialmente o que faltou foi uma combinação efetiva - como é a história efetiva (wirkliche Historie) teorizada por Foucault ao definir uma figura não teleológica com que repensar o passado, como a genealogia (Foucault, 1977, p. 43) - que articulasse poéticas e políticas da restituição que remetessem ao passado desapropriado, resgatando-o do seu recalcamento ou denegação.

Nesse quadro, emergem projetos literários bastante diferenciados, mas que perseguem como fim comum esta indenização do passado como reconstrução de um rosto desfigurado. $\mathrm{Na}$ tensão irredutível entre subjetividade e realismo, entre antiliteratura e culto supremo da forma literária, afirmaram-se obras emblemáticas de algumas aporias constitutivas desse corpo literário. Podemos citar uma, relativamente recente e impressionante, que é $K$. de Bernardo Kucinski, o romance (mas não desprovido de experiência, até direta e pessoal) sobre o desaparecimento forçado nos tempos da repressão violenta do Estado (Kucinski, 2011, p. 178).

O problema da restituição talvez represente, no plano conceitual, o campo mais problemático e ao mesmo tempo central da elaboração pós-autoritária que se associa à violência da Ditadura Militar no Brasil. Não só porque o campo intersecta inúmeros saberes (direito, psicanálise, crítica literária e cultural, filosofia política, entre outros), mas também porque um dos marcos do terror de Estado praticado no século XX no subcontinente - com a destruição total do corpo do inimigo morto e ocultamento de seus rastros -, de que o Brasil foi um dos primeiros terrenos empíricos, põe drasticamente em crise e faz colapsar a noção jurídica de restituição ad integrum que é projetada no plano da impossibilidade ou das possibilidades exclusivamente fantasmáticas. Poder-se-ia observar que a restituição diz respeito também ao gênero, no sentido que o feminino é sempre, como observa Adriana Cavarero, a dimensão desvocalizada pelo pensamento que, desde Platão, é dominado pelo logos masculino (Cavarero, 2003, p. 110-114).

O conceito de restitutio ad integrum pertence a uma das mais antigas tutelas, já prescrita pelo direito romano, de acordo com a qual se restabelece um status quo ante que foi modificado de modo ilegítimo. Pertencia aos poderes extraordinários do Praetor, que podia exercê-lo também em nome de ausentes, menores ou incapacitados, implicando assim o exercício de uma subjetividade ética (Santí, 2005, p. 88). Perante o dilema de uma restituição juridicamente impossível ou filologicamente arriscada, ao mesmo tempo vale a pena não abdicar da ideia de 
uma restituição pelo menos no plano simbólico do objeto perdido, resgatada do silêncio e que restaure as vozes silenciadas pelo tempo (Vecchi, 2014, p. 133-149).

A urgência da restituição foi um traço dominante do período da abertura política depois da democratização da Nova República, que teve na literatura, em particular na narrativa, seu território privilegiado, muito antes que a história pudesse articular uma política de reconhecimento indiciário como a que de fato está ocorrendo hoje, há quase três décadas do encerramento do ciclo autoritário. A questão do "gênero" no sentido da forma evidencia-se de modo macroscópico. A subjetividade testemunhal, que corresponde ao ponto de vista singular do relato, cria um excesso de recordações, experiências, ângulos de visão e uma extrema exiguidade de memória viva que possa se tornar compartilhável e eventualmente pública. Encontramos no Brasil deste tempo a grande aporia historiográfica do século $X X$, que se funda sobre a irredutibilidade do testemunho na história, apesar da dominância que o testemunho adquire na cena pública, inclusive para promover uma revisão do passado. A restituição, portanto, fica prejudicada justamente porque se evade da moldura (indefinível em seu contorno) de sua impossível integridade e da necessidade de repensá-la num plano que intersecta a subjetividade ética, que possibilita uma rearticulação ao mesmo tempo imprópria e, mesmo por isso, própria.

$\mathrm{Na}$ discussão crítica que se associa à produção memorialista e corresponde a uma preocupação sobre o inexorável escoar do tempo se define a ideia de uma arte filológica que, pela metáfora do restauro textual, possa resgatar palimpsestos do passado enterrados por baixo de outras escritas ou silêncios, desempenhando uma função vicária de recomposição de simulacros explícitos da história. Desse modo, pela força ficcional de novos pactos, preenche-se os ocos e vazios que perturbam a construção de uma narração compartilhada da vivência inclusive traumática.

Não podemos pensar esse contexto pós-autoritário sem recorrer à obra de Ana Maria Machado. O que se desenvolve lucidamente, em alguns seus romances, é uma reflexão pelo viés da narrativa sobre as políticas da memória, na paisagem inquieta do Brasil pós-ditatorial. Em particular, nossa análise se concentra em duas obras cruciais para pensar estética e historicamente o Brasil daquele tempo, a partir de uma fundamental disjunção de gênero: Tropical sol da liberdade, de 1988, e Canteiros de Saturno, de 1991.

As duas obras representam contribuições pioneiras em relação à presença de escritas de mulheres sobre o período da ditadura brasileira e pós-ditadura. Em 2006, Maria Lygia Quartim de Moraes escreve que o registro da experiência das mulheres pode ser procurado apenas nos livros construídos a partir de depoimentos ou de reconstrução histórica, porque

o levantamento da literatura de testemunho revela um fato interessante: são raríssimos os livros escritos por mulheres, não obstante a significativa participação feminina na luta armada e as torturas, mortes e desaparecimentos de corpos. Muitas das que sobreviveram à tortura e à prisão são jornalistas, professoras universitárias e intelectuais acostumadas a escrever. No entanto, quarenta anos após, poucos são os livros em que as mulheres são o sujeito do discurso (Moraes, 2006, p. 8).

O vazio e longo esquecimento de vozes é uma linguagem que precisa ser decifrada. Em Formen des Vergessens, Aleida Assmann (2016) analisa as práticas do esquecer e afirma que o esquecer é a modalidade fundamental da vida humana e social; o lembrar, ao contrário, implica um esforço, uma rebelião, um veto contra o tempo e o rumo das coisas (Assmann, 2019, p. 39). De fato, independentemente do gênero, todas as memórias traumáticas colocam a questão da luta contra o silêncio e contra o "consolo", ou a tentação do esquecimento. Todavia, precisamos distinguir o silêncio regenerador do silêncio cúmplice; três formas de silêncio se reforçam reciprocamente e problematicamente: o silêncio defensivo dos autores de abusos, o silêncio sintomático das vítimas traumatizadas e o silêncio cúmplice da sociedade (Assmann, 2019, p. 84). A predisposição e a vontade da sociedade de quebrar ou não quebrar o silêncio (o que Maurice Halbwachs (2007) chama de "quadros sociais da memória") é fundamental para suportar ou dificultar o esforço (e a dor) de lembrar das vítimas (e sobretudo para possibilitar ou obstaculizar a reivindicação dos seus direitos). No caso das memórias traumáticas femininas, os vazios e esquecimentos tomam também uma dimensão de gênero: a dificuldade e a 
possibilidade de lembrar e contar devem ser relacionadas com a condição e consideração históricas das mulheres. Também nas lutas clandestinas contra a ditadura as mulheres sofreram formas de machismo e discriminação (Teles, 1999); a afirmação de suas memórias de protagonistas exigia não apenas o ajustamento do "quadro social da memória", mas também uma radical revolução feminista, pela afirmação do próprio papel e da própria fala no espaço social e político nacional, já que, de fato, o surgimento do feminismo brasileiro está inseparavelmente ligado à experiência da ditadura (Pinto, 2003).

O estudo recente de Eurídice Figueiredo, A literatura como arquivo da ditadura brasileira (2017), parece confirmar o longo vazio de escritas femininas sobre a experiência da ditadura, mas mostra uma mudança e uma "reemersão" que podemos colocar nos últimos vinte anos (2000 até hoje). Segundo a periodização proposta pela autora, no primeiro período (1964-1979) e no segundo período (1980-2000), quase não aparecem romances escritos por mulheres. Os romances de Ana Maria Machado representam, de fato, algumas das poucas exceções desse momento histórico em que, como já foi dito, a literatura cumpriu o papel de restituição e reconhecimento que a política ainda não conseguia alcançar. Ainda mais em relação à experiência das mulheres. Com razão, Ana Maria Colling já afirmava em 1997 que, nas interpretações elaboradas sobre a ditadura civil-militar, os espaços de atuação política da mulher eram silenciados e que os principais protagonistas acabavam sendo os homens, apesar da importante participação das mulheres na luta armada (Ridenti, 1990) e no processo de redemocratização do Brasil, como mostra Sonia Alvarez (1990), que emprega a expressão "engendering democracy in Brazil". Anos mais tarde, em 2004, a mesma Colling afirmava que os estudos de gênero ligados às ditaduras estavam se desenvolvendo graças às transformações das perspectivas historiográficas, voltadas a recuperar os pontos de vista de sujeitos "subalternos" e minorias excluídas das narrações hegemônicas. De fato, com a exceção do trabalho pioneiro Memórias das mulheres do exílio (Costa et al., 1980), é apenas entre o fim dos anos 1990 e os anos 2000 que surgem importantes contribuições sobre a experiência das mulheres durante os anos da ditadura, ${ }^{1}$ que, de certa forma, contribuindo para a visibilização destas experiências, influenciaram novas narrativas. Várias publicações literárias escritas a partir da própria biografia ou da experiência pessoal dos anos da ditadura foram lançadas anos depois dos eventos narrados, por exemplo, os textos Nem tudo é silêncio, de Sônia Bischain (2010); Tempos Extremos, de Miriam Leitão (2014); Volto na semana que vem, de Maria Pilla (2015); e Outros contos, de Maria Valéria Rezende (2015).

Pioneiras na produção feminina produzida no contexto da redemocratização, as duas intensas narrativas de Ana Maria Machado trabalham com uma periodização histórica precisa, criando - e é esta uma singularidade relevante - um olhar combinado e duplo sobre a ditadura e a transição que lhe seguiu. Nos dois romances, a história atribulada do Brasil contemporâneo se torna algo mais que um simples pano de fundo útil para a contextualização. Torna-se matéria viva e ao mesmo tempo íntima da narração que desempenha uma função - complexa - de reflexão crítica e não imediata sobre ela. O que é importante ressaltar, nesse quadro, é a relevância do gênero (sujeito) como elemento disjuntivo para realizar a leitura alternativa da história. Em suma, a forma literária absorve um movimento da história que é reduzido a material essencial da construção estética. Não há, portanto, num sentido estrito, um engajamento de realismo ilusório, como ocorre quando a transposição da experiência e do mundo parece imediata e facilmente viável pela abertura ingênua da exposição do eu (como copiosamente ocorreu), mas uma lúcida desmontagem crítica que encontra na forma literária seu território principal de ação reflexiva.

Essa tendência é evidente em Tropical sol da liberdade, onde o problema da escrita (de uma escrita aliás que se confronta com o problema da diferença sexual) é crucial, operando uma inversão brusca a uma dominante literária da década em que a literatura se dobrava à urgência

\footnotetext{
${ }^{1}$ Em 1998, foi publicado outro texto de depoimentos, Mulheres, militância e memória: histórias de vida, histórias de sobrevivência, organizado por Elisabeth F. Xavier Ferreira; em 2010, o importante texto Luta: um substantivo feminino, organizado por Tatiana Merlino; e, em 2014, os importantes relatórios recolhidos pela Comissão Nacional da Verdade.
} 
de encontrar uma forma - também acrítica - para a história. A relação entre crítica e produção alternativa da escrita - portanto outra escrita - é um motivo conjugativo na reconstrução do que foi a época da Ditadura Militar, flagrada do ângulo, como Lena observa, da margem que remete para a condição do sujeito da fala e decide se expor na cena (pública), isto é, "contar no palco a tal trajetória de uma mulher na periferia dos acontecimentos" (Machado, 2012, p. 46).

Essa postura decorre de uma revisão cortante do que foi escrito na ilusão de um pacto mimético que pudesse dar conta do tempo vivido abrindo-se como uma totalidade inacessível, tornando-se artificialmente transitivo porque é "mais honesto assumir logo que essa história de depoimento pessoal é uma ficção, uma parte do gênero romanesco [...] Quer dizer, uma maneira inventada de contar as coisas fazendo de conta que elas aconteceram assim, mas não aconteceram" (Machado, 2012, p. 32). O que o romance mostra é como a ficção histórica é necessária para conduzir o trabalho da memória, mas, ao mesmo tempo, como esta ficção sempre deve ser metaficcionalizada, encontrando seu apego na escrita sobre a escrita e projetando-se no horizonte do que costumamos em filosofia chamar de ética do discurso (o texto dentro do texto). A discussão estética (algum realismo é viável e como consegui-lo?) é já um modo de incorporação crítica da história tornada material íntimo, inscrito na vivência da personagem (de ficção) ou como se lê no romance: "Conta o teu lado, Lena. Isso que você está chamando de visão da periferia. Em que medida uma ação que você escolheu afetou a sua vida" (Machado, 2012, p. 34).

Obra dentro da obra (na linha de uma tradição vasta da literatura brasileira que tem entre seus ápices Caetés, de Graciliano Ramos, só para dar um exemplo eloquente) o dispositivo que se articula é sofisticado e permite despotencializar muitas das aporias críticas implícitas no androcentrismo da escrita da história. O que se inscreveno romance, portanto, é um autorretrato (ficcional e marcado pela diferença sexual) de uma história que não se deixa emoldurar. Opção esta plenamente política, porque no autorretrato, na representação do eu pelo eu, que assim envereda pela via intransitável percorrida de Durer a Montaigne, de Kierkegaard a Baudelaire e a Proust - a via da autorrepresentação -, se dá uma exposição do próprio aberta para a partilha. Como observa Franco Rella:

É a ostensão ilimitada de mim que torna visível o mundo - a minha experiência do mundo - para o outro. É no meu espanto diante da impudica ostensão do outro que descubro e vejo o mundo que ele vê, e que se ilumina também para mim, saindo das trevas e da noite em que ele me escondia. A autorrepresentação é então cosmogônica, enquanto transforma em mundo o deserto de ruínas que a construção do Eu puro do pensamento tinha deixado atrás de si (Rella, 1998, p. 12, tradução nossa).

Se repararmos, é o caminho oposto ao do gênero testemunhal, em que o mundo se constrói a partir do eu: aqui é o eu que se reconstrói, pela exposição diferencial, a partir da experiência do tempo. O sujeito assim "restituído" se pode tornar antes de tudo sujeito político que emerge enquanto "evento do discurso" (Bhabha, 1997, p. 40, tradução nossa). Privilegiar esse lado estético não é um atalho na procura de um "real" que permanece impossível, pelo contrário supõe um trabalho mais paciente e complexo, atravessando um território com um percurso que nada tem de imediato, mas que se aprofunda tortuosamente por outros caminhos, porque "ficção precisa ter uma verossimilhança que raramente a verdade tem" (Machado, 2012, p. 42). No entanto, fica patente que o que está em jogo é mesmo uma aposta com a história, num momento de crise aberta, de que, porém, não se controlam o perfil e as possíveis saídas. Ao mesmo tempo, fica também claro que o que se encontra em risco é a perda, o esvaziamento de memória, como se a experiência fosse desapossada e sua restituição, portanto, sua memória residuária, impossível, ou já completamente escoada:

Talvez fosse mesmo inevitável. O ritmo brasileiro de fazer História é mesmo muito lento, cheio de avanços e recuos, pensava Lena. Mas, cada vez mais, ela se surpreendia meio impaciente com essas demoras e contratempos. A transição para a democracia demorava tanto, sem chegar a se completar, já ia quase ficando mais longa do que a própria ditadura. E por mais que a mulher entendesse que o tempo histórico é outro, para o tempo de sua vida esses anos eram demais, era algo que estava sendo roubado dela sem possibilidade de devolução (Machado, 2012, p. 155). 
A partir dessa atitude literária e ao mesmo tempo crítica, em que os ecos, inclusive da história a mais traumática, vibram como sentimento e emoção, consegue-se um exercício também terapêutico de reapropriação do passado (diria de desalienação dos fetiches da história oficial), soldando a esfera privada e o espaço público, tornando íntima a história do país. Aqui também se enxerga o elemento canônico que encontramos em clássicos como os de Graciliano Ramos, Lima Barreto, Cyro dos Anjos, Cornélio Penna e na poesia de Drummond, ou seja, uma vertente altamente seletiva da modernidade literária politicamente crítica dos valores do patriarcado. A diferença sexual, o gênero, é o eixo de conjugação entre as duas dimensões, privada e pública, própria e coletiva, oikonômica e política, e é a sua força débil, hesitante, que habita dois lugares, duvidosa, portanto, o inesperado evento discursivo que promove uma reescrita radical da vivência.

Nessa perspectiva, o segundo romance de Ana Maria Machado, Canteiros de Saturno, conecta-se ao anterior incorporando já a sua força de revisão crítica da circunstância histórica e estética do Brasil da Nova República. No entanto, muda de estratégia, inclusive porque a forma leva sempre, ainda que indiciariamente, rastros do tempo, como se, pela forma, o movimento de repetição e variação alterasse sempre o sentido do romance. A cena histórica está escancarada aos olhos do leitor inclusive através de algumas personagens que coagulam marcos ideológicos e desempenham a função de testemunhas do tempo (um tempo que vai da campanha das Diretas Já, de 1983-84, ainda na época da ditadura, ao governo Sarney e aos primórdios, gráceis no plano econômico e institucional, da nova democracia) como é o caso de Romero, pai de Mariana, "um termômetro do Brasil" (Machado, 1991, p. 171). A rearticulação, no entanto, e com ela a possibilidade de restituição de um passado já outro, do qual o país tenta reapropriarse, não ocorre através de uma segunda escrita (embora os planos segundos sejam incontáveis, como o diálogo entre história e ficção de Bárbara e Isadora), mas por meio de uma dupla opção sobre a dimensão privada - o mundo de Antígona -, que é aberta e repolitizada, e, sobretudo, por um amplo ato de autor sobre os tempos que se intersectam, confundem-se, redescobrem sua dispersa proximidade da dimensão curvilínea do tempo mítico (onde acaso e destino se conjugam e o tempo dá amplas voltas desenhando círculos impensados). Da politização da estética do romance anterior, em Canteiros se passa a outra politização, que diz respeito às relações humanas e à reinscrição no humano da forma de vida, como se outra ressignificação fosse possível quando as relações não recalcam, mas resgatam a relação do "homem" (aqui surge o limite linguístico, androcêntrico, do conceito de homem como humano, porque como a narrativa mostra, é do feminino que se trata), da história, da cultura, com a natureza. O espaço dessa recombinação - que é conflituosa, não conciliatória - são as mulheres que encenam um aspecto impensado do político (portanto efetiva e teoricamente "impolítico"), ou seja, a democracia não como uma construção jurídica, um dispositivo histórico, mas a democracia como capacidade, sempre em combinação com a arte, que perpassa até o horizonte ideológico.

A qualidade do feminino, nesse quadro, desestabiliza algo que desde os primórdios pode ser visto dentro de outra moldura mitológica, como o erro de Édipo, assim como o observa Adriana Cavarero: mito que inaugura uma longa vicissitude filosófica, de acordo com a qual a mulher está na posição do objeto (e pensando também como a Esfinge representa androcentricamente a monstruosidade do feminino retratado pelo homem, seu lado terrível e animal) ou seja, "é pensada, representada e definida do ponto de vista do Homem, diferente dele porque ele é o paradigma do gênero humano, a mulher, mesmo sendo um nome geral, nunca é universal" (Cavarero, 2009, p. 69, tradução nossa).

São grandes figurações do feminino aquelas que marcam a restituição do tempo em Canteiros de Saturno. Antes de tudo, dentro do enredo, temos a figura matriarcal de Leonora, cujo tempo biográfico - um tempo último aliás - moldura o romance e cuja arte de biombos, assim como aquela da madeira-matéria para seu parceiro Nicolau, procura um retorno à natureza. Natureza esta que se alia assim com a arte e com a responsabilidade de não perder o valor próprio da matéria, fazendo com que outra relação seja possível entre salvação e resgate do passado no presente:

O que construía partia necessariamente de uma destruição anterior, e não se podia esquecer disso nem enganar a si mesmo. Daí que tinha uma responsabilidade enorme em 
não desperdiçar, tinha que procurar o melhor, o mais bonito, o mais funcional. Como um escritor que fosse consciente das vidas vegetais que custa o papel em que escreve e em que seus livros são impressos, e se recusasse a compactuar com o descartável. E, por outro lado, sentia uma obrigação de repor essas árvores, além de reciclar a madeira de casas velhas, sempre que possível (Machado, 1991, p. 290-291).

Também nesse romance como no outro, arte e ética se conjugam para redefinir uma relação viável do bom e do bonito. No entanto, é através de outras figuras femininas que emergem as permanências do "erro de Édipo", da marginalidade do objeto feminino na economia do desejo masculino. É o caso da empregada nordestina Marly, vítima permanente de muitas violências masculinas do passado, que, no momento em que reencontra um elo possível, ainda que abstrato, com suas origens, é morta sofrendo um estupro. Evento trágico que se une, através de uma trama densa e sábia, à culpa do homem, o Carlos, o Tuca, que, ao mesmo tempo, alimenta uma dupla relação com Bárbara e Isadora.

Aqui, a relação feminina, sua trama que é comunicação e texto - sendo a arte de narrar separada desde as origens edipianas, da ordem discursiva da filosofia (Cavarero, 2009, p. 72) e, portanto, patrimônio específico do tecer comunicativo das mulheres -, mostra como no novo Brasil, inclusive naquele mais aparentemente crítico em relação aos autoritarismos do passado, as velhas relações patriarcais e sexistas se perpetuam. Essa mesma relação feminina mostra ainda a capacidade de renovação feminina das relações pessoais e sociais que representa a efetiva fratura no exercício de restituição do tempo desapropriado, revertendo a traição sofrida em proteção compartilhada. A "capacidade" é aquela que as mulheres têm de redefinir sempre, discursiva e praticamente, os pontos de contatos, as interseções, do privado e do público, da casa e da pólis, expondo a dúvida de Antígona - dúvida etimológica que combina a dimensão privada e o que, fora da tragédia e dentro da modernidade, é chamado de espaço público, ou seja, o graphos nomos político e o agraphos nomos dos laços familiares. Uma prática a que podemos dar o nome de política, que se articula, como mostra Ana Maria Machado, por meio de uma trama feminina de narrações, gestos criativos, relações, adversos à dimensão abstrata e racionalizante e muito mais ancorados no corpo e na voz. E é por isso que é justamente a heroína sofocliana que define o tempo novo do país: "A história brasileira dos últimos tempos vinha criando figuras femininas de uma estatura fora do comum. Grandes figuras trágicas, dissera Isadora numa conversa. Antígona. Mãe coragem. Outros personagens desse tipo" (Machado, 1991, p. 181).

Essa restituição, no feminino, do passado perdido, dos cacos de traumas e perdas, das cicatrizes expostas que se vocalizam a partir de um olhar disjuntivo e lateral, pode assim realizar-se através do resgate (da restituição) de vozes periféricas e abandonadas, que mostram outra possibilidade de contar uma história lacunosa e incompleta, mas que na força débil e marginal do discurso das mulheres encontra registro e consistência, tornando-se uma efetiva possibilidade de salvar um passado de outro modo perdido para sempre e sobretudo para todos. Sem diferença sexual, mas com uma cicatriz que marcou em particular uma condição histórica sobre outras, uma condição justamente feminina: "Não dava para esquecer nem confundir datas. Mais que qualquer outro, esse tempo passou deixando marcas na carne viva de cada mãe" (Machado, 2012, p. 71).

Essa capacidade de restituição da voz feminina no contexto da elaboração dos anos de chumbo é a coluna vertebral dos dois textos de Ana Maria Machado, que tem o mérito de abrir o caminho e explicitar a necessidade de uma "memória feminina" (sobretudo em Tropical sol da liberdade) e da busca da forma da escrita da história das mulheres (sobretudo em Canteiros de Saturno), mostrando a difícil relação entre história e memória. Como afirma a historiadora Michelle Perrot, a memória, sendo uma forma de relação com o tempo e o espaço, é profundamente sexuada. Desse modo, tornam-se necessárias práticas de memórias femininas porque existe uma particularidade "na medida em que as práticas socioculturais presentes na tripla operação que constitui a memória - acumulação primitiva, rememoração, ordenamento da narrativa - está imbricada nas relações masculinas/femininas reais e, como elas, é produto de uma história" (Perrot, 1989, p. 18). Em Tropical sol da liberdade, o tema da memória feminina, 
por um lado, se articula em torno da reflexão sobre a memória vivida e das vivências e, por outro lado, sobre a busca da forma da escrita, comunicação e transmissão desta memória.

Uma das principais vivências a ser enfrentada é aquela do exílio: "Muita gente já tinha escrito sobre a tortura, não era isso que ela queria abordar. Preferia se concentrar numa evocação do exílio, tal como ela viu e viveu, dividir essa experiência com quem ficou, compartilhar o sonho e o pesadelo" (Machado, 2012, p. 136).

No texto, além da experiência da protagonista Lena, são contadas várias histórias de exílio, mostrando a complexidade de experiências aparentemente menos afetadas pela brutalidade que sofreu quem ficou e, ao mesmo tempo, a condição específica dos/as exiliados/as brasileiras/os ou sul-americanas/os na contínua confrontação com os países que os acolheram, sentindo-se sempre atrasados e tendo a sensação de que "a utopia sonhada pode até existir, mas seu povo está barrado do ingresso no paraíso" (Machado, 2012, p. 177). A história de Lena, e de outras mulheres citadas nesse romance, por ter visibilizado essa condição de exílio a partir da especificidade de ser mulher, parece um contraponto literário do livro de depoimentos Memórias das mulheres do exílio, em que é traçado o ambicioso projeto de descrever uma condição histórica coletiva - "Esta é a minha história, a sua história, a história dela. Este livro é uma obra coletiva" (Costa et al., 1980, p. 13) - e de explicitar a dificuldade própria das mulheres em contar e transmitir suas experiências durante os anos de chumbo: "nem sempre as mulheres se sentiram incluídas quando partiu o convite inicial para que os exilados escrevessem as suas memórias. [...] Era a tentativa de recuperar a nossa experiência no que ela tem também de específico, torná-la descritível para transmiti-la" (Costa et al., 1980, p. 14).

Outro aspecto em que aparecem especificidades da memória feminina é representado por essa busca da forma de comunicação escrita e transmissão da memória. A interseção entre lembranças dolorosas (privadas) e dever da memória (pública), ou seja, essa capacidade feminina de articulação de esfera privada e espaço público de que falamos, é explicitada e comprovada pela mesma reflexão sobre as formas de escritas, pelo afastamento dos depoimentos e pela escolha da literatura. Tanto o desenvolvimento de estudos de gênero sobre o período da ditadura quanto a proliferação de depoimentos e relatos ajudarão muito a reavaliação do papel das mulheres e a transmissão dessa memória, mas a literatura é capaz de ativar outros mecanismos que superam a dimensão individual e biográfica, criando uma relação política e inclusiva com o leitor, construída através do recurso ao imaginário, ao "possível que aconteceu". O perigo do "autoritarismo da afetividade" (Machado, 2012, p. 172), de que se fala no romance, representa, ao mesmo tempo, o problema dessa difícil interseção e o impulso da chegada à literatura para enfrentar memórias traumáticas:

Outros artistas podem exercitar com mais liberdade seus talentos. O escritor, não. $\mathrm{O}$ significado das palavras é imediatamente conceitual, ligado a referências externas. Se ele estiver numa roda de conhecidos e brincar com as palavras num contexto de alegria, o resultado é humor - um sucesso. Se manejar as palavras na dor, ferido, pode dar em ironia um desastre do ponto de vista social. A não ser que se censure. E não só no momento. Mesmo depois, na hora de escrever. Se Lena começasse a contar suas dores de filha, magoaria seus pais. Se falasse em suas dores de amiga, magoaria outras pessoas amadas. E era principalmente da dor que ela precisava falar. O jeito era se censurar. E aprender a inventar novas formas de burlar essa censura, como se já tivera que falar anos a fio com as proibições policiais da ditadura no jornal. Seria possível conseguir isso? [...] Vai ver, estava inventando um jeito inconsciente de não poder escrever, sem se sentir culpada. Até que aprendesse a tecer no texto uma trama como a do sonho. Uma coisa no lugar de outra, um personagem somando vários, outro se desdobrando em uma porção... Para que o relato se fizesse, apesar da censura, por cima do autoritarismo da afetividade (Machado, 2012, p. 172).

De outra forma, Canteiros de Saturno confirma esta metarreflexão sobre o poder específico da literatura, explicitando também seu papel político na sociedade:

uma sociedade voltada para os valores de se ter mais e não de ser mais vai necessariamente procurar diminuir a leitura de ficção. Porque a ficção subverte os próprios alicerces dessa sociedade, abala a ênfase no ter. Para se defender, essa sociedade vai 
privilegiar outras formas literárias, não as que aprofundam uma dramatização, como o romance ou o teatro. Ela vai repudiar a narrativa de ficção porque sabe que é uma ameaça. E vai ficar dando valor a manuais de comportamento, biografias documentadas, reportagens, teses, ensaios, memórias, enfim, toda forma de expressão que pareça mais segura, que não enverede pelos terrenos movediços de uma linguagem cambiante (Machado, 1991, p. 193-194).

Canteiros de Saturno, chegando a encenar essas metarreflexões, aborda também a questão da relação entre memória feminina e forma da escrita da história das mulheres no tempo: "tempo, tempo, sempre o tempo" (Machado, 1991, p. 16), uma frase-mantra que se repete várias vezes, pondo o problema da preservação e politização da memória: "O povo brasileiro tem péssima memória, esquece tudo..." (Machado, 1991, p. 42). As mulheres, fortes, são as grandes protagonistas do romance. E ao já citado diálogo entre Bárbara (a historiadora) e Isadora (a pesquisadora de literatura) é confiada a grande reflexão sobre a forma de narrar e contar histórias e memórias de mulheres. Bárbara contava detalhes do papel das mulheres na história brasileira e "Isadora nunca tinha pensando que, de repente, a história do Brasil podia virar uma coisa tão interessante [...] O passado ficava vivo em suas palavras" (Machado, 1991, p. 111). Ao mesmo tempo, através das palavras de Isadora, a ficção é relida na sua forte ligação com o real e no seu papel político: "Afinal de contas, ficção é isso - fingimento. É a mesma palavra. Escrever é fingir. Mas é fingir tanto e com tanta intensidade que acaba sendo verdade. Ou é fingir a partir de algo intensamente real" (Machado, 1991, p. 113). Até chegar à conclusão explicitada por uma das duas mulheres para resolver a grande pergunta "Como é que a gente pode saber o que não está nos livros?" (Machado, 1991, p. 109) sobre a memória feminina: "Acho que, de certo modo, a gente está buscando coisas complementares e atacando o mesmo problema. Eu fico procurando as mentiras escondidas na aparente verdade histórica. Você sai atrás da verdade que está por baixo" (Machado, 1991, p. 114).

Essa troca de perspectivas e busca de formas de escritas das memórias é interessante porque testemunha a importância da reflexão sobre a transmissão social da memória feminina. Os livros de Ana Maria Machado, por introduzir esses temas e metarreflexões em contextos da época da ditadura e da redemocratização, transmitem a urgência dessa memória - "Lembrança não tem jeito. Teoricamente, a gente pode dar corte, interromper, desviar. Só que, na prática, não se manda na memória, ela é que manda na gente. Insiste em vir como quer e quando quer. Ou some e se esconde, por mais que se puxe" (Machado, 2012, p. 273) - e também uma forte crítica aos processos de reconstrução e comunicação das memórias traumáticas brasileiras. Uma constante e geral crítica à história do Brasil e às retóricas imaginárias brasileiras aparece, explícita e implicitamente: "A gente fica sonhando, imaginando que é a terra das belas árvores, mas no fundo é mesmo o país da madeira derrubada para tingir pano. Ou essa sua ideia engraçada: Brasil, terra da brasa" (Machado, 2012, p. 175).

A dupla cicatriz, aquela do Brasil da ditadura e a das vozes femininas nas suas urgências de buscar uma forma de contar a história pessoal e coletiva - respondendo ao problema da escrita que se confronta também com o problema da diferença sexual e a resistência ao esquecimento é a profunda diretriz desses romances inscritos no sóbrio e difícil período da história brasileira. A dimensão de gênero age possibilitando a constituição e a defesa de uma memória feminina sobre um tempo traumático, uma leitura alternativa da história, uma "outra escrita" e restituição do que foi a época - ainda presente - da ditadura militar.

\section{Referências}

ALVAREZ, Sonia E. (1990). Engendering democracy in Brazil. Princeton: Princeton University Press.

ASSMANN, Aleida (2002). Ricordare: forme e mutamento della memoria culturale. Bologna: Il Mulino.

ASSMANN, Aleida (2016). Formen des Vergessens. 4. ed. Göttingen: Wallstein Verlag.

ASSMANN, Aleida (2019). Sette modi di dimenticare. Bologna: Il Mulino. 
BHABHA, Homi K. (1997). Introduzione: narrare la nazione. In: BHABHA, Homi K. Nazione e narrazione. Roma: Meltemi.

CAVARERO, Adriana (2003). A più voci. Filosofia della espressione vocale. Milano: Feltrinelli.

CAVARERO, Adriana (2009). Tu che mi guardi, tu che mi racconti. Filosofia della narrazione. Milano: Feltrinelli.

COLLING, Ana Maria (1997). A resistência da mulher à ditadura militar no Brasil. Rio de Janeiro: Rosa dos Ventos.

COLLING, Ana Maria (2004). As mulheres e a Ditadura Militar no Brasil. In: CONGRESSO LUSO-AFROBRASILEIRO DE CIÊNCIAS SOCIAIS, 8., 16-18 set. Coimbra. Anais [...] Coimbra: Centro de Estudos Sociais da Universidade de Coimbra. Disponível em: http://www.ces.uc.pt/lab2004/pdfs/Ana_Maria_Colling.pdf. Acesso em: 5 jul. 2015.

COSTA, Albertina de Oliveira et al. (1980). Memórias das mulheres do exílio. Rio de Janeiro: Paz e Terra.

FIGUEIREDO, Eurídice (2017). A literatura como arquivo da ditadura brasileira. Rio de Janeiro: Editora 7Letras.

FOUCAULT, Michel (1977). Nietzsche, la genealogia, la storia. In: FOUCAULT, Michel. Microfisica del potere. Torino: Einaudi.

HALWBACHS, Maurice (2007). La memoria collettiva. Milano: UNICOPLI.

KUCINSKI, Bernardo (2011). K. São Paulo: Expressão Popular.

MACHADO, Ana Maria (1991). Canteiros de Saturno. Rio de Janeiro: Francisco Alves Editora.

MACHADO, Ana Maria (2012). Tropical sol de liberdade. Rio de Janeiro: Objetiva.

MORAES, Maria Lygia Quartim de (2006). Da luta armada ao feminismo. In: ENCONTRO ANUAL DA ANPOCS, 30., Caxambu-MG, 24-28 out. Anais [...] Caxambu-MG: ANPOCS. Disponível em: https://www.anpocs.com/index.php/papers-30-encontro/gt-26/gt09-16/3290-mmoraes-da-luta/file. Acesso em: 10 dez. 2019.

PERROT, Michelle (1989). Práticas da memória feminina. Revista Brasileira de História, São Paulo, v. 9, n.18, p. 9-18, ago/set. Disponível em: https://www.anpuh.org/arquivo/download?ID_ARQUIVO=3846. Acesso em: 10 dez. 2019.

PINTO, Céli Regina Jardim (2003). Uma história do feminismo no Brasil. São Paulo: Editora Fundação Perseu Abramo.

RELLA, Franco (1998). Negli occhi di Vincent: l'io nello specchio del mondo. Milano: Feltrinelli.

RIDENTI, Marcelo Siqueira (1990). As mulheres na política brasileira: os anos de chumbo. Tempo Social, São Paulo, v. 2, n. 2, p. 113-128, dez. Disponível em: http://www.revistas.usp.br/ts/article/view/84806. Acesso em: 10 dez. 2019.

SANTÍ, Enrico M. (2005). Ciphers of history: latin american readings for a cultural age. New York: Palgrave Macmillan.

SELIGMANN-SILVA, Márcio (1999). A literatura do trauma. Cult, São Paulo, n. 23. Dossiê literatura de testemunho. s.p.

TELES, Maria A. de Almeida (1999). Breve história do feminismo no Brasil. São Paulo: Editora Brasiliense.

VECCHI, Roberto (2014). O passado subtraído da desaparição forçada: Araguaia como palimpsesto. Estudos de Literatura Brasileira Contemporânea, Brasília, n. 43, p. 133-149, jan./jun. Disponível em: https://periodicos.unb.br/index.php/estudos/article/view/9950/8788. Acesso em: 10 dez 2019. 